Short Communication http://ajol.info/index.php/ijbcs http://indexmedicus.afro.who.int

\title{
Effect of methanol, n-hexane and aqueous extract of Irvingia gabonensis leaf on castor oil-induced diarrhoea in albino rats
}

\author{
Bright Chukwuebuka UNAEZE ${ }^{1 *}$, Ruben Udeozor NWOBU ${ }^{2}$, Cajetan Elochukwu ILO ${ }^{3}$ \\ and Ebele Chinwe EJIKE ${ }^{4}$ \\ ${ }^{I}$ Department of Medical Laboratory Sciences, Faculty of Health Sciences, Nnamdi Azikiwe University, \\ Awka, Nigeria. \\ ${ }^{2}$ Department of Applied Microbiology \& Brewing, Faculty of Biosciences, Nnamdi Azikiwe University, \\ Awka, Nigeria. \\ ${ }^{3}$ Department of Pharmacology and Therapeutics, College of Health Sciences, Nnamdi Azikiwe University, \\ PMB 5001, Nnewi, Anambra State, Nigeria. \\ ${ }^{4}$ Department of Medical Microbiology, Chukwuemeka Odumegwu Ojukwu University, Awka Campus, Nigeria. \\ ${ }^{*}$ Corresponding author; E-mail: brighterworld2000@yahoo.com, Phone: +234-08034013222
}

\section{ABSTRACT}

Bush mango leaf (Irvingia gabonensis) is commonly used locally to treat diarrhoea. The present study evaluated the anti-diarrhoea effect of this plant extract on albino rats induced with castor oil. Fresh tender leaf of this plant was collected, air-dried, powdered and percolated in n-hexane, methanol and aqueous solvents. Diarrhoea was induced with castor oil on albino rats using standard procedures. The extract (100, 250 and 500 $\mathrm{mg} / \mathrm{kg}$ ) in a dose dependent manner, significantly protected the rat against diarrhoea induced experimentally with castor oil in terms of nature and number of stool droppings within $3 \mathrm{hrs}$ of administration of extract, there was no significant difference when compared with the control drug (Loperamide) $(\mathrm{P}>0.05)$. The study justifies the ethno pharmacological uses of this medicinal plant for treatment of diarrhoeal disease.

(C) 2017 International Formulae Group. All rights reserved.

Keywords: Diarrhoea, castor oil, Irvingia gabonensis.

\section{INTRODUCTION}

Diarrhoea can be defined as the increased frequency of bowel movements, accompanied by a loose consistency of stools. Worldwide distribution of diarrhoea accounts for more than 5-8 million deaths each year in infants and small children less than 5 years of age. World health organization (WHO) estimate that in 1998 (Jaiarj et al., 2000), about 7.1 million deaths occurred due to diarrhoea (Lin et al., 2002). On a worldwide basis, 750 million cases are reported in children below 5 years in Asia, Latin America and Africa resulting in 4-5 million deaths (Abdullahi et al., 2001).

However, the incidence of diarrhoeal diseases varies greatly with the seasons and a child's age. The youngest children are most vulnerable. Incidence is highest in the first two years of life and declines as a child grows older. Mortality from diarrhoea has declined over the past two decades from an estimated 5 million deaths among children under 5 years to 1.5 million deaths in 2004 (WHO, 2004). 
In an effort to tackle the problems of diarrhoea, the world Health Organization (WHO) has established diarrhoea disease control programme (DDC) which includes studies of traditional medicinal practices together with the evaluation of health education and prevention approaches $(3,4)$. In most parts of the developing countries, particularly Africa, the use of herbal remedies in management of diarrhoea is a common practice. Irvingia gabonensis is a tree plant popularly known as wild or Africa mango. The plant occurs freely in many parts of Africa. It belongs to the family Irvingiaceae, It is identified by various names such as "bush mango", "dika nut" tree, "Ugiri" in Igbo, "Goron" or "Biri" in Hausa and "Apon" in Yoruba. The variability of the phytochemical compounds of each plant may explain why traditional medicine uses the combination of both plants to increase the antioxidant activities. (Koevi et al., 2015).

They have been proved to contain pharmacologically active ingredients which have over the years been exploited in traditional medicine for the treatment of various human and animal diseases (Adamu et al., 2006).

Recently, Raji et al. (2001) reported anti-diarrhoeal and anti-ulcer properties of $I$. gabonensis. Okorondu et al. (2013) observed that the inhibitory action of the plant extracts could be attributed to the presence of the phytochemical constituents in the plant extracts such as alkaloid, flavonoid and saponin. Castor oil is a ricinoleate (Mckeon et al., 1999) and its diarrhoea inducing property is known to be due to its active metabolite ricinoleic acid which increases peristaltic activity and alters permeability of the intestinal mucosa membrane to electrolytes. The objective of the study was to determine the therapeutic effect of the plant extract in rats induced with castor oil.

\section{MATERIALS AND METHODS \\ Plant collection}

Irvingia gabonensis leaf was collected from Lilu town in Ihiala L.G.A of Anambra State, Nigeria. The plant was identified and authenticated in the Department of botany,
Nnamdi Azikiwe University, Awka Nigeria where the sample was deposited. The leaves spread out and dried on a clean surface under a shade at room temperature to exclude direct Sunlight in order to prevent the active constituents of the leaves from being degraded due to photochemical reactions. It was air dried for about eight days after which, it was observed to be dried. The dried leaves were gathered, and crushed with grinder. The powder was weighed using an electric weighing balance by Kern ALS 220 - 4. The powder was then stored in an air tight bag at room temperature and used for further extraction.

\section{Preparation of plant extract}

The ground leaf was prepared in three ways to get the extracts.

\section{Aqueous extract (Maceration Method)}

Maceration method was used for aqueous extraction and powdered leaf of Irvingia gabonensis was used. $150 \mathrm{~g}$ of the plant was weighed and put in $375 \mathrm{ml}$ of distilled water and allowed to stand for $48 \mathrm{hrs,}$ agitate or shake for 45 mins. The extract was filtered using British standard mesh filter and first muslin cloth and concentrated by using air drying under constant air current and water bath at $50{ }^{\circ} \mathrm{C}$. The extract was then transferred into a clean container and stored in the refrigerator until required for use.

\section{Organic solvent extraction by maceration}

This was carried out at Pharmacognosis Department, Faculty of Pharmaceutical Sciences, Agulu. $150 \mathrm{~g}$ of the plant sample was transferred into $1000 \mathrm{ml}$ volumetric flask, and then $375 \mathrm{ml}$ of solvent (methanol and n-hexane) were added. This was covered and allowed for $48 \mathrm{hrs}$ with continuous shaking, filtered and transferred to rotary evaporator for concentration. The extract was then transferred into a clean container and stored in the refrigerator until required for use.

\section{Extraction by Soxhlet method}

This method was carried out by continuously extracting a sample with a nonpolar organic solvent for about 4-6 hrs. 


\section{Experimental animal and diet}

In the study, thirty-three (33) of about 8 weeks old healthy rats (Rattus norvegicus) weighing $92-138 \mathrm{~g}$ were used. The rats were kept in standard metal cages obtained from the faculty. Controlled conditions of temperature $\left(25 \pm 20{ }^{\circ} \mathrm{C}\right)$, relative humidity $(50 \pm 15 \%)$ and normal photoperiod $(12-12$ hrs light - dark cycle) were maintained. Free access to standard pellet and water was ensured. Acclimatization of the rats to the metal cages ( $4-6$ rats/cage) was done for seven days and maintained according to the NIH guideline for care and use of laboratory Animals (Saha et al., 2001).

Drug: Loperamide $(2 \mathrm{mg}$ ) was obtained from Pharmacy Department, Nnamdi Azikiwe University Hospital, Nnewi, Anambra State, Nigeria.

\section{Anti-diarrhoea assay}

The plant extract with three different solvents (n-hexane, aqueous and methanol) were used for the study. Eleven (11) cages allotted three albino rats each, out of the eleven cages, two were used as negative control and positive control, and nine cages were used as test groups.

The animals were fasted for $12 \mathrm{hrs}$ and weighed. $2 \mathrm{ml}$ of castor oil were given intragastically to each rat in each group to induced diarrhoea (Yegnanarayan and Shostri 1982), while papers were dropped underneath of the cages. Faecal materials were checked for the nature of stool passage; $30 \mathrm{~min}$ after administration of castor oil, diarrhoea was established, $2 \mathrm{ml}$ of water was given to negative control and $2 \mathrm{ml}$ of anti-diarrhoea (Loperamide) was given to positive control and volume equivalent of plant extract (100, 250 and $500 \mathrm{mg} / \mathrm{kg}$ ) were given to test groups. Faecal materials were checked for consistency/frequency every $30 \mathrm{~min}$ for the characteristic droppings. The presence/absence of fluid material in the stool that stained the absorbent paper placed beneath the cages and nature of stool passed during $3 \mathrm{hrs}$ period was recorded to determine the effect of plant extract on castor oil induced diarrhoea. Their absence was recorded as a good protection from diarrhoea; also reduction in diarrhoea (watery Stool) is a protection.

\section{Statistical analysis}

The statistical method used was 2- way ANOVA and Bonferroni post-test. This was done at $\mathrm{P}<0.05$ level of significance.

\section{RESULTS}

Tables $1-3$ show the results of effect of methanol, n-hexane and aqueous extracts of Irvingia gabonensis leaf on castor oil induced diarrhoea. After administration of castor oil, the rats were defecating watery stools (ws), then after administration of extracts, the watery stooling stopped. The methanol and nhexane extracts of Irvingia gabonensis show that in high doses $(500 \mathrm{mg} / \mathrm{kg})$, the number of stool droppings within $3 \mathrm{hrs}$ of administration of extract was one (1) while the number of no stool dropping (No defecation) within $3 \mathrm{hrs}$ of administration of extract was five (5), when compared with the anti-diarrhoea drug (loperamide) $(\mathrm{P}<0.05)$ that had the same result. Then, the aqueous extract of Irvingia gabonensis shows that in high dose (500 $\mathrm{mg} / \mathrm{kg}$ ), the number of stool droppings within $3 \mathrm{hrs}$ of administration of extract was two (2). In other ways, the methanol and n-hexane extracts of Irvingia gabonensis were more effective than the aqueous extract of Irvingia gabonensis at high doses (500 mg/ $\mathrm{kg})$. whereas, the aqueous and n-hexane extracts had the same number of stool dropping (2) and the number of no stool dropping (4) within $3 \mathrm{hrs}$ at low $(100 \mathrm{mg} / \mathrm{kg})$ and middle $(250 \mathrm{mg} / \mathrm{kg})$ doses (Tables 2 and 3$)$.

The Methanol extract of Irvingia gabonensis had the same result at middle dose $(250 \mathrm{mg} / \mathrm{kg})$ with anti-diarrhoea drug (loperamide) (Table 1).

The extracts significantly protected rats against castor oil- induced diarrhoea when compared with the control as evident in the nature and prolongation of onset. Loperamide (2 $\mathrm{mg} / \mathrm{kg}$ ) also significantly protected rats against castor oil-induces diarrhoea. The extracts effect was dose dependent (100, 250 and $500 \mathrm{mg} / \mathrm{kg}$ ). 
Table 1: Effect of methanol extract of Irvingia gabonensis on castor oil- induced diarrhoea.

\begin{tabular}{|c|c|c|c|c|c|c|c|c|c|c|c|}
\hline \multirow{2}{*}{$\begin{array}{l}\text { Nature of stool, } 30 \mathrm{~min} \\
\text { after administration of } \\
\text { castor oil }\end{array}$} & \multirow{2}{*}{$\begin{array}{c}\text { Extract doses } \\
(\mathrm{mg} / \mathrm{kg})\end{array}$} & \multirow{2}{*}{$\begin{array}{l}\text { Weight } \\
\text { (g) }\end{array}$} & \multirow{2}{*}{$\begin{array}{l}\text { Volume Equivalent to } \\
\text { dose administered (ml) }\end{array}$} & \multicolumn{6}{|c|}{ Nature of stool at time interval ( 30 minutes). } & \multirow{2}{*}{$\begin{array}{c}\text { Number of stool } \\
\text { dropping within } 3 \mathrm{hrs} \\
\text { of adm. of extract }\end{array}$} & \multirow{2}{*}{$\begin{array}{c}\text { Number of no } \\
\text { stool dropping } \\
\text { within } 3 \mathrm{hrs}\end{array}$} \\
\hline & & & & $0-30$ & $\begin{array}{c}31- \\
61\end{array}$ & $\begin{array}{c}62- \\
92\end{array}$ & $\begin{array}{l}93- \\
123\end{array}$ & $\begin{array}{r}124- \\
154\end{array}$ & $\begin{array}{l}155- \\
185\end{array}$ & & \\
\hline Watery stool & 100 & 125 & 0.13 & SWS & ND & ND & ND & ND & NS & 2 & 4 \\
\hline Watery stool & 250 & 119 & 0.29 & ND & ND & ND & ND & NS & ND & 1 & 5 \\
\hline Watery stool & 500 & 118 & 0.59 & ND & ND & ND & ND & ND & HS & 1 & 5 \\
\hline Watery stool & Loperamide & 121 & 0.41 & ND & ND & ND & ND & ND & HS & 1 & 5 \\
\hline
\end{tabular}

WS = watery stool; SWS = semi - watery stool; $\mathrm{HS}=$ Hard stool; NS = Normal stool; ND= No defecation

Table 2: Effect of aqueous extract of Irvingia gabonensis on castor oil- induced diarrhoea.

\begin{tabular}{|c|c|c|c|c|c|c|c|c|c|c|c|}
\hline \multirow{2}{*}{$\begin{array}{l}\text { Nature of stool, } 30 \mathrm{~min} \\
\text { after administration of } \\
\text { castor oil. }\end{array}$} & \multirow{2}{*}{$\begin{array}{l}\text { Extract } \\
\text { doses } \\
(\mathrm{mg} / \mathrm{kg})\end{array}$} & \multirow[t]{2}{*}{$\begin{array}{l}\text { Weight } \\
\text { (g) }\end{array}$} & \multirow{2}{*}{$\begin{array}{l}\text { Volume Equivalent } \\
\text { to dose administered } \\
\left(\begin{array}{l}\text { (ml) }\end{array}\right.\end{array}$} & \multicolumn{6}{|c|}{$\begin{array}{c}\text { Nature of stool at time interval (30 } \\
\text { minutes) }\end{array}$} & \multirow{2}{*}{$\begin{array}{l}\text { Number of stool } \\
\text { dropping within } 3 \mathrm{hrs} \text { of } \\
\text { adm. of extract }\end{array}$} & \multirow{2}{*}{$\begin{array}{c}\text { Number of no } \\
\text { stool dropping } \\
\text { within } 3 \text { hrs. }\end{array}$} \\
\hline & & & & $\begin{array}{l}\mathbf{0}- \\
30\end{array}$ & $\begin{array}{c}31- \\
61\end{array}$ & $\begin{array}{l}62- \\
92\end{array}$ & $\begin{array}{l}93- \\
123\end{array}$ & $\begin{array}{l}124- \\
154\end{array}$ & $\begin{array}{c}155- \\
185\end{array}$ & & \\
\hline Watery stool & 100 & 118 & 0.11 & ND & NS & ND & NS & ND & ND & 2 & 4 \\
\hline Watery stool & 250 & 129 & 0.32 & NS & ND & ND & ND & ND & HS & 2 & 4 \\
\hline Watery stool & 500 & 119 & 0.59 & NS & ND & ND & ND & ND & NS & 2 & 4 \\
\hline Watery stool & Loperamide & 121 & 0.41 & ND & ND & ND & ND & ND & HS & 1 & 5 \\
\hline
\end{tabular}

WS = watery stool; SWS = semi - watery stool; HS $=$ Hard stool; NS = Normal stool; ND = No defecation.

Table 3: Effect of n-hexane extract of Irvingia gabonensis on castor oil- induced diarrhoea.

\begin{tabular}{|c|c|c|c|c|c|c|c|c|c|c|c|}
\hline \multirow{2}{*}{$\begin{array}{l}\text { Nature of stool, } 30 \mathrm{~min} \\
\text { after administration of } \\
\text { castor oil }\end{array}$} & \multirow{2}{*}{$\begin{array}{c}\text { Extract } \\
\text { doses } \\
(\mathrm{mg} / \mathrm{kg})\end{array}$} & \multirow[t]{2}{*}{$\begin{array}{l}\text { Weight } \\
\text { (g) }\end{array}$} & \multirow[t]{2}{*}{$\begin{array}{l}\text { Volume Equivalent to } \\
\text { dose administered (ml) }\end{array}$} & \multicolumn{6}{|c|}{$\begin{array}{c}\text { Nature of stool at time interval (30 } \\
\text { minutes) }\end{array}$} & \multirow{2}{*}{$\begin{array}{l}\text { Number of stool } \\
\text { dropping within } 3 \mathrm{hrs} \mathrm{of} \\
\text { adm. of extract }\end{array}$} & \multirow{2}{*}{$\begin{array}{l}\text { Number of no } \\
\text { stool dropping } \\
\text { within } 3 \text { hrs. }\end{array}$} \\
\hline & & & & 0- & $\begin{array}{c}31- \\
61\end{array}$ & $\begin{array}{l}62- \\
92\end{array}$ & $\begin{array}{l}93- \\
123\end{array}$ & $\begin{array}{c}124- \\
154\end{array}$ & $\begin{array}{l}155- \\
185\end{array}$ & & \\
\hline Watery stool & 100 & 138 & 0.14 & ND & NS & ND & NS & ND & ND & 2 & 4 \\
\hline Watery stool & 250 & 113 & 0.28 & NS & ND & ND & ND & ND & HS & 2 & 4 \\
\hline Watery stool & 500 & 113 & 0.59 & ND & ND & ND & ND & ND & HS & 1 & 5 \\
\hline Watery stool & Loperamide & 121 & 0.41 & ND & ND & ND & ND & ND & HS & 1 & 5 \\
\hline
\end{tabular}

WS = watery stool; SWS = semi - watery stool; $\mathrm{HS}=$ Hard stool; NS = Normal stool; ND = No defecation 


\section{DISCUSSION}

The results of the present study suggested that the methanol, n-hexane and aqueous extracts of Irvingia gabonensis had significant anti-diarrhoea effects. Castor oil is ricinoleate (Mckeon et al., 1999) and its diarrhoea inducing property is known to be due to its active metabolic ricinoleic acid which increases peristaltic activity and alters permeability of the instestinal mucosa membrane to electrolyte, particularly $\mathrm{Na}^{+}, \mathrm{Cl}^{-}$ (Adzu et al., 2003) and water (Capasso et al., 1994).

Castor oil is also reported to induce diarrhoea by increasing the volume of intestinal content by prevention of the reabsorption of water.

The secretory diarrhoea is associated with an activation of $\mathrm{Cl}$ - channels, causing $\mathrm{Cl}$ efflux from the cell, the efflux of $\mathrm{Cl}$ - results in massive secretion of water into the intestinal lumen and profuse watery diarrhoea (Longanga et al., 2000).

Diarrhoea was established 30 mins after administration of castor oil to the rats at volume equivalent to their weights. The results revealed that the extract was able to stop the diarrhoea in the rats within $3 \mathrm{hrs}$ of therapy, showing that they exhibited anti-diarrhoeal effects. Effect of the extracts on castor oil induced diarrhoea in rat also showed protection ability of the extract was high. Abdulrahman et al. (2004) reported the same. The above findings are therefore, suggestive of nonspecific mechanism of action of anti-diarrhoeal activity of the extract. Moreso Unaeze et al. (2017) also suggested that the plant had anti diarrhoea effect.

\section{Conclusion}

In conclusion, the present study has shown that extract of irvingia gabonensis is a potent anti- diarrhoeic agent which can be used for the effective management of diarrhoea.

\section{COMPETING INTERESTS}

The authors declare that there are no conflicts of interest.

\section{AUTHORS' CONTRIBUTIONS}

This work was carried out in collaboration between all authors. Author CEI wrote the protocol, the first draft of the manuscript and managed the literature searches. Author ECE managed the analyses of the work and performed the statistical analysis. Author BCU carried out all laboratory works. Author RUN designed the study and supervised the work. All authors read and approved the final manuscript.

\section{ACKNOWLEDGEMENTS}

The Authors are grateful to Anagonye Calistus of Biochemistry Department Nnamdi Azikiwe University Awka, Anambra State for his technical assistance.

\section{REFERENCES}

Abdullahi AL, Agho MO, Amos S, Gamaniel KS, Wambebe C. 2001. Antidiarrhoeal activity of the aqueous extract of Terminalia avicennoides roots. Phytother Res., 15(5): 431- 434.

Abdulrahman F, Inyang I S, Abbah J, Binda L, Amos S, Gamaniel K. 2004. Effect of aqueous leaf extract of Irvingia gabonensis on gastrointestinal tract in rodents. Indian J. Exp Biol., 42(8): 787791.

Adamu M, Fluck H, Croshaw B. 2006. Medicinal Plants and Their Uses. W. Feulsham and Comp. 1td: New York; 715.

Adzu B, Amos S, Amizan MB, Gamaniel K. 2003. Evaluation of the anti-diarrhoeal effects of Zizyplus spina-christi stem bark in rats, Acta Trop., 87(2): 245-250.

Capasso F, Mascolo N, Izzo AA, Gaginella T S. 1994. Dissociation of castor oilinduced diarrhoea and intestinal mucosal injury in rat: effect of NG-nitro-Larginine methyl ester. British Journal of Pharmacology, 113: 1127-1130.

Jaiarj P, Wongkrajang Y,Thongpradilchote S, Peungvicha P, Burly-Apraphatsara N, Opartkiattikul N. 2000. Guava leaf extract, and topical haemostasis. Photother. Res., 14(5): 388-391.

Koevi KKA, Millogo V, Hzounda Fokou JB, Sarr A, Quedraogo GA, Bassene E. 2015. Phytochemical Analysis and 
Antioxidant activities of Combretum molle and Pericopsis laxiflora. Int. J. Biol. Chem. Sci., 9(5): 2423-2431.

Lin J, Puckree T, Mvelase TP. 2002. Antidiarrhoeal evaluation of some medicinal plants used by Zulu traditional healers. $J$. Ethnopharmacol., 79(1): 53-56.

Longanga_Otshudi A, Vercruysse A, Foriers A. 2000. Contribution to the ethnobotanical, phytochemical and pharmacological studies of traditionally used medicinal plants in the treatment of dysentery and diarrhea in Lomela area, Democratic Republic of Congo (DRC). $J$ Ethnopharmacol., 71(3): 411-423.

Mckeon TA, Lin JJ, Stafford AE. 1999. Biosynthesis of Recinoleate in Castor oil: Adv Exp Med. Biol., 464: 37-47.

Okorondu SI, Akujobi CO, Okorondu JN, Anyado-Nwadike $\quad$ SO. 2013. Antimicrobial activity of the leaf extracts of Moringa oleifera and Jatropha curcas on Pathogenic bacteria. Int. J. Biol. Chem. Sci., 7(1): 195-202.
Raji Y, Ogunwande IA. Adesola JM, Bolarinwa AF. 2001. Anti-diarrhogenic and anti-ulcer properties of Irvingia gabonensis in rats. Pharmaceut Biol., 39(5): 340.

Saha S, Sieghart W, Fritschy JM, Batten TFC, McWillia PN. 2001. y-Aminobutyric acid receptor $\left(\mathrm{GABA}_{\mathrm{A}}\right)$ Subunits in rat nucleus tractus solitarii (MTS) revealed by PCR and immunohistochemistry. Molecular and Cellular Neuroscience, 17: 241-257.

Unaeze BC, Ilo CE, Egwuatu C, Orabueze I, Obi E. 2017. Anti- diarrhoeal effects of three Nigerian medicinal plant extracts on E. coli- induced diarrhoea. Int. J. Biol. Chem. Sci., 11(1): 414-419.

WHO. 2004. Basic Laboratory Procedures in Clinical Bacteriology ( $2^{\text {nd }}$ edn). World Health Organization: Geneva.

Yegnanarayan R, Shostri DS. 1982.Comparison of antidiarroheal activity of sons drugs in experimental diarrhea, Indian J. Pharmacol., 14(4): 293-299. 